Doc. dr. sc. Maša Marochini Zrinski ${ }^{1}$

Mr. sc. Anamarija Kvaternik ${ }^{2}$

\title{
OČUVANJE AUTORITETA I NEPRISTRANOSTI SUDBENE VLASTI KAO DOPUŠTENO OGRANIČENJE PRAVA NA SLOBODU IZRAŽAVANJA - HRVATSKA I KONVENCIJSKA PERSPEKTIVA
}

$U D K: 342.56: 342.727(497.5)$

DOI: $10.31141 /$ zrpfs.2021.58.142.1055

Izvorni znanstveni rad

Primljeno: 15. 07. 2021.

Sloboda izražavanja, kao jedan od temelja demokratskog društva, spada u kvalificirano konvencijsko pravo koje je uvijek, kada su za to ispunjene pretpostavke, podložno ograničenjima. Jedno od dopuštenih ograničenja, odnosno legitimnih ciljeva taksativno navedenih u čl. 10 . Konvencije, za ograničenje slobode izražavanja jest i očuvanje autoriteta i nepristranosti sudbene vlasti. Također, Ustav Republike Hrvatske jamči slobodu izražavanja u čl. 38., dok čl. 16. propisuje dopuštena ograničenja sloboda iz Ustava, iako ne navodi posebno očuvanje autoriteta i nepristranosti sudbene vlasti. Unatoč nevelikom broju predmeta u kojima se ispitivala dopuštenost ograničenja slobode izražavanja radi očuvanja autoriteta i nepristranosti sudačke vlasti, iste autorice smatraju ih značajnima te će se iz tog razloga prikazati slučajevi iz domaće prakse, i to na svim razinama sudovanja, kao i najznačajnije presude Europskog suda koje se bave upravo navedenim legitimnim ciljem kao dopuštenim ograničenjem slobode izražavanja. Autorice su spomenute slučajeve prikazale prvenstveno kroz dvije skupine predmeta: one u kojima su osobe koje su smatrale da im je povrijeđena sloboda izražavanja bili novinari, kao i one u kojima se radilo o odvjetnicima koji su provodili slobodu izražavanja u sudnici ili izvan nje.

Ključne riječi: sloboda izražavanja, očuvanje autoriteta $i$ nepristranosti sudbene vlasti, dopušteno ograničenje slobode izražavanja, nacionalni sudovi, Europski sud za ljudska prava

\section{UVOD}

Sloboda izražavanja, kao bitan temelj demokratskog društva i jedan od osnovnih preduvjeta za njegov napredak i za razvoj svakog čovjeka, ${ }^{3}$ štiti se, bez iznimke, svim

1 Pravni fakultet Sveučilišta u Rijeci, docent na Katedri za Teoriju prava i države, filozofiju prava, ljudska prava i javnu upravu, mmarochini@ pravri.hr, ORCID: https://orcid.org/0000-0002-8441-2277. 4126 .

2 Zajednički odvjetnički ured Kvaternik, ured@odvjetnik-kvaternik.hr, ORCID: 0000-0002-4207-

3 Hanyside protiv Ujedinjenog Kraljevstva, zahtjev br. 5493/72, od 7. prosinca 1976., § 49. 
međunarodnim i regionalnim dokumentima za zaštitu ljudskih prava. ${ }^{4}$ Međutim, pravo na slobodu izražavanja nije apsolutno već kvalificirano pravo podložno ograničenjima. Niz je dopuštenih ograničenja slobode izražavanja, no ovaj rad bavit će se prvenstveno ograničenjima radi očuvanja autoriteta i nepristranosti sudačke vlasti kao jednog od taksativno navedenih legitimnih ciljeva iz čl. 10. Konvencije za zaštitu ljudskih prava i temeljnih sloboda (dalje u tekstu: Konvencija, EKLJP). ${ }^{5}$

Kada govorimo o pravu na slobodu izražavanja prema Konvenciji, ono ima, kao i sva kvalificirana prava sadržana u Konvenciji, dvodijelnu strukturu. Naime, prvi stavak propisuje pravo na slobodu izražavanja dok drugi stavak propisuje pretpostavke pod kojima se to pravo može ograničiti od strane javne vlasti. Upravo zbog navedene strukture, u gotovo svim slučajevima koji se tiču pitanja navodne povrede prava na slobodu izražavanja, Europski sud za ljudska prava (dalje u tekstu: Europski sud, ESLJP) provodi tzv. test nužnosti u demokratskom društvu. ${ }^{6}$

S druge strane, čl. 38. Ustava $\mathrm{RH}^{7}$ također jamči slobodu izražavanja, pri čemu je zanimljivo spomenuti kako je u toj odredbi poseban naglasak stavljen na zaštitu novinarskog izvještavanja i pristupa informacijama, kao i na pristup informacijama kojima raspolažu tijela javne vlasti, dok su dopuštena ograničenja sloboda i prava zajamčenih Ustavom propisana čl. 16. bez navođenja očuvanja autoriteta i nepristranosti sudačke vlasti kao posebnog legitimnog cilja.

S druge strane, Konvencija, kao tekst nastao 1950. godine, ne sadrži razrađeno jamstvo prava u samom članku, no svakako je Sud svojom praksom pružio ekstenzivnu zaštitu samog prava, slijedeći praksu evolutivnog i autonomnog tumačenja čl. 10. čime pruža učinkovitu zaštitu prava zajamčenih čl. 10. Naime, jedan od glavnih načina prilagodbe Konvencije današnjim zahtjevima u društvu, bez ikakvih promjena u izvornom tekstu, jest putem tumačenja iste, što pruža Sud. Ne referirajući se ovdje na sve metode tumačenja kojima se služi Sud, ${ }^{8}$ za

4 Opća deklaracija o ljudskim pravima, usvojena i proglašena na Općoj skupštini Ujedinjenih naroda, Rezolucijom 217 A (III), čl. 11., MEĐUNARODNI PAKT O GRAĐANSKIM I POLITIČKIM PRAVIMA* usvojen na Općoj skupštini Ujedinjenih naroda, 16. prosinca 1966. godine (rezolucija br. 2200 A /XXI/), čl.. 19., POVELJA EUROPSKE UNIJE O TEMELJNIM PRAVIMA (2016/C 202/02), čl. 11., Američka konvencija o ljudskim pravima (tzv. Pakt iz San Josea) iz 1969., čl. 13., Afrička povelja o ljudskim pravima i pravima naroda (Povelja iz Banjula) iz 1986., čl. 9.

5 Zakon o potvrđivanju EKLJP-a i Protokola br. 1., 4., 6., 7., 11. i 14. uz EKLJP, NN, Međunarodni ugovori, dalje u tekstu: MU, br. 18/97, 6/99 - pročišćeni tekst i 8/99, Protokoli br. 12., 13. i 14., Zakon o potvrđivanju Protokola br. 12. uz EKLJP, Zakon o potvrđivanju Protokola br. 13. uz EKLJP, o ukidanju smrtne kazne u svim okolnostima, NN, MU br. 14/02 i Zakon o potvrđivanju Protokola br. 14. uz EKLJP, o izmjeni nadzornog sustava Konvencije, NN, MU br. 1/06. Još: objave o stupanju na snagu Protokola br. 12. uz EKLJP, NN, MU, br. 9/05, Protokola br. 13 uz EKLJP, NN, MU, br. 13/03 i Protokola br. 14. uz EKLJP, NN, MU, br. 2/10.

6 Primjenom navedenog testa Sud ispituje radi li se uopće o pravu koje spada u opseg čl. 10. EKLJP-a, tj. radi li se o (dopuštenoj) slobodi izražavanja, a ne npr. o govoru mržnje ili pozivanju na nasilje, te je li došlo do miješanja u neko od navedenih prava od strane javne vlasti. Nadalje, Sud ispituje je li miješanje bilo u skladu sa zakonom, je li bilo u skladu s jednim od legitimnih ciljeva taksativno navedenih u st. 2., čl. 10. Konvencije (jedan od kojih je i očuvanje autoriteta i nepristranosti sudbene vlasti), te je li bilo nužno u demokratskom društvu (neodloživa društvena potreba), odnosno, je li miješanje bilo razmjerno.

7 Ustav Republike Hrvatske, pročišćeni tekst, NN 56/90, 135/97, 08/98, 113/00, 124/00, 28/01, 41/01, 55/01, 76/10, 85/10, 05/14.

8 Vidi detaljnije u Marochini, 2014. 
slobodu izražavanja svakako su najvažniji načelo živućeg instrumenta odnosno evolutivnog tumačenja, načelo autonomnog tumačenja i načelo slobodne procjene država. Do primjene načela slobodne procjene država kao sastavnog dijela načela supsidijarnosti, dolazi se odgovarajući na posljednje pitanje u testu nužnosti kada je Sud u poziciji donijeti odluku je li ograničenje prava bilo razmjerno, odnosno je li država prekoračila dopušteno polje slobodne procjene. Sve navedeno ispituje se od slučaja do slučaja, no Sud je ipak utvrdio određene kriterije koje uzima u obzir prilikom odlučivanja. Upravo će se ovim radom pokušati ekstrahirati ključne kriterije za odlučivanje o razmjernosti miješanja u slobodu izražavanja radi očuvanja autoriteta i nepristranosti sudačke vlasti.

\subsection{Općenito o čl. 10. Konvencije}

Definicija koju je iznjedrio Sud u predmetu Handyside protiv Ujedinjenog Kraljevstva $a^{9}$ ne definira, niti pobliže objašnjava što ulazi u opseg slobode izražavanja, no svakako je vrlo korisna polazna točka i zapravo omogućuje naslutiti kako ce Europski sud autonomno i široko tumačiti što predstavlja izražavanje. Literatura najčešće naglašava sljedeće komponente slobode izražavanja: sloboda imanja mišljenja (kao apsolutna sloboda i preduvjet za druge slobode zajamčene čl. 10.); sloboda primanja informacija i ideja; sloboda širenja informacija i ideja; te pristup informacijama (Bychawska-Siniarska, 2017., str. 11-19). Također, lista oblika izražavanja zaštićenih čl. 10 svakako je iscrpna, stoga smatramo kako nema niti potrebe nabrajati sve oblike izražavanja koji su se pojavili u kontekstu čl. 10, no svrsishodno je spomenuti samo neke od oblika izražavanja poput: izdavanja knjige, ${ }^{10}$ pisanja novinskih članaka, ${ }_{11}^{11}$ prikazivanja filma, ${ }^{12}$ umjetničko izražavanje $\mathrm{kroz}$ slike ${ }^{13}$ (i filmove i fotografije), izražavanje putem televizije, ${ }^{14}$ ili izražavanje putem interneta. ${ }^{15}$

9 Handyside protiv Ujedinjenog Kraljevstva, § 49: ,sloboda izražavanja predstavlja jednu od ključnih osnova demokratskog društva, jedan od osnovnih uvjeta njegovog napretka i razvoja svakog čovjeka..."

10 Handyside protiv Ujedinjenog Kraljevstva.

11 Sunday Times protiv Ujedinjenog Kraljevstva (br. 1), zahtjev br. 6583/74, od 26. travnja 1979.; Sunday Times protiv Ujedinjenog Kraljevstva (br. 2), zahtjev br. 13166/87, od 26. studenoga 1991.

12 Wingrowe protiv Ujedinjenog Kraljevstva, zahtjev br. 17419/90, od 15. studenoga 1996.; Otto Preminger Institut protiv Austrije, zahtjev br. 13470/87, od 20. rujna 1994. (u oba predmeta do miješanja je došlo u vidu zabrane prikazivanja filma).

13 Muller i drugi protiv Švicarske, zahtjev br. 10737/84, od 24. svibnja 1988. (gdje je do miješanja došlo zbog zapljene takvih slika).

14 Jersild protiv Danske, zahtjev br. 15890/89, od 24. rujna 1994. (gdje je do miješanja došlo jer je sankcioniran novinar i urednik dokumentarnog filma na kojem su svoje rasističke stavove izrazili pripadnici skinheadsa).

15 Ashby Donald i drugi protiv Francuske, zahtjev br. 36769/08, od 10. siječnja 2013.; Delfi As protiv Estonije, zahtjev br. 64569/09, od 16. lipnja 2015. 
S druge strane, ograničenje slobode izražavanja možemo naći u izricanju novčanih kazni, zapljeni slika, ${ }^{16}$ zabrani distribucije knjiga, ${ }^{17}$ letaka, ${ }^{18}$ zabrani objavljivanja novinskih članaka odnosno cenzuri prije objavljivanja koja se smatra najopasnijim oblikom miješanja, ${ }^{19}$ zabrani prikazivanja filma ${ }^{20}$ pa čak i zatvorskim kaznama. ${ }^{21}$

Unatoč nevelikom broju predmeta u kojima se ispitivala dopuštenost ograničenja slobode izražavanja radi očuvanja autoriteta i nepristranosti sudačke vlasti, iste svakako smatramo značajnima, kako na nacionalnoj tako i na europskoj razini te će se iz navedenog razloga prikazati slučajevi iz domaće prakse, i to na svim razinama sudovanja, kao i najznačajnije presude Suda koje se bave upravo navedenim legitimnim ciljem kao dopuštenim ograničenjem slobode izražavanja.

\section{OČUVANJE AUTORITETA I NEPRISTRANOSTI SUDBENE VLASTI KAO DOPUŠTENO OGRANIČENJE PRAVA NA SLOBODU IZRAŽAVANJA}

Autoritet je, najopćenitije govoreći, ugled, zasluženo povjerenje, priznato značenje osoba ili institucija koje uživaju opći ugled i imaju velik, ${ }^{22}$ u konkretnom slučaju, društveni, utjecaj na način da kroz pravosudni sustav putem odluka koje donose odlučuju o pravima i obvezama pravnih i fizičkih osoba. S druge strane, pravo na pravično suđenje zahtijeva nepristranost suca, što podrazumijeva da sudac nije opterećen predrasudama u vezi s odlukom koju donosi, da ne dopusti da prilikom suđenja bude opterećen izvanpostupovnim informacijama (bilo da se radi o stavu javnosti ili nekom drugom obliku pritiska), već da svoje mišljenje temelji na onim činjenicama koje su utvrđene u sudskom postupku. Pravo na suđenje pred nepristranim sudom znači da sudac nema poseban interes u određenom slučaju, kao i da nema već formirano mišljenje o postupku ili strankama. ESLJP kroz svoju praksu tumači pojam nepristranosti kao odsustvo predrasuda ili pristranosti u postupku. Kod utvrđivanja pojma nepristranosti, ključan je odnos suda prema strankama, pa je ESLJP u predmetu Hauschildt protiv Danske postavio dva kriterija, prema kojima procjenjuje je li došlo do povrede nepristranosti: „Postojanje nepristranosti u smislu čl. 6. stavak 1. mora biti utvrđeno prema subjektivnom kriteriju, što znači na temelju

16 Muller i drugi protiv Švicarske.

17 Handyside protiv Ujedinjenog Kraljevstva.

18 Open Door Counselling i Dublin Well Woman protiv Irske, zahtjevi br. 14234/88 i 14235/88, od 19. listopada 1992. (br. 2).

19 Sunday Times protiv Ujedinjenog Kraljevstva (br. 1); Sunday Times protiv Ujedinjenog Kraljevstva

20 Otto Preminger Institut protiv Austrije; Wingrowe protiv Ujedinjenog Kraljevstva.

${ }_{21}$ Surek protiv Turske (br. 1), zahtjev br. 26682/95, od 8. srpnja 1999. (VV); Castells protiv Španjolske, zahtjev br. 11798/85, od 23. travnja 1992.

${ }^{22}$ Hrvatska enciklopedija, mrežno izdanje. Leksikografski zavod Miroslav Krleža, 2021. <http:// www.enciklopedija.hr/Natuknica.aspx?ID=4770, pristupljeno 25. kolovoza 2021. 
osobnog uvjerenja suca koji odlučuje o predmetu, a također i na temelju objektivnog kriterija kojim se isključuje postojanje bilo kakve opravdane sumnje u njegovo takvo odlučivanje."23

Kao što je već naglašeno, ključno pitanje u većini predmeta koji se tiču povrede jednog od kvalificiranih prava jest ono o nužnosti ograničenja u demokratskom društvu, odnosno razmjernosti. Ne postoji univerzalan odgovor na ovo pitanje, niti je Sud postavio jasne kriterije, već se prosuđuje od slučaja do slučaja, dajući veliku slobodu Sudu u donošenju presuda, čime raste nesigurnost država i podnositelja zahtjeva u pogledu očekivanog ishoda postupka odnosno vrste donesene presude. Međutim, kako će se vidjeti iz analizirane prakse u predmetima u kojima se radi o ograničenju slobode izražavanja radi zaštite autoriteta i nepristranosti sudbene vlasti, Sud je dao određene smjernice pomoću kojih se može (donekle) predvidjeti stav koji će Sud zauzeti kod donošenja odluke.

Za ovaj su rad odlučni predmeti u kojima je država ograničila slobodu izražavanja određenim sankcijama za podnositelja, a kada govorimo o predmetima gdje je ispitivano jesu li podnositelji poštovali neovisnost i autoritet sudbene vlasti, one se mogu naći u obliku ograničenja putem zabrane objavljivanja (rjeđe) za novinare i novčanih kazni (češće) za odvjetnike. Stoga navedene predmete treba podijeliti u dvije skupine, one u kojima su podnositelji zahtjeva bili novinari odnosno nakladnici, te one u kojima su podnositelji zahtjeva bili odvjetnici. Prije prikaza prakse ESLJP-a, osvrnut ćemo se na predmete koji su se vodili pred domaćim sudovima, a uključuju kaznenopravnu i građanskopravnu zaštitu sudaca odnosno novinara, nakladnika i odvjetnika u procesnim ulogama tužitelja/tuženika, privatnog tužitelja i okrivljenika.

\subsection{Očuvanje autoriteta i nepristranosti sudbene vlasti - praksa Nacionalnih sudova}

Opće je načelo i dužnost novinara, sukladno Kodeksu časti hrvatskih novinara, u svom radu pridonositi jačanju pravne države, pridržavati se Ustava i zakona Republike Hrvatske, njegovati kulturu i etiku javne riječi i uvažavati civilizacijska dostignuća i vrijednosti pridržavajući se profesionalnih etičkih načela s jedne strane, te pružajući zaštitu neotuđivom pravu pojedinaca i pravu javnosti na informaciju s druge strane..$^{24}$

Jedan od zanimljivijih predmeta u kojem se novinar našao u ulozi okrivljenika jest kazneni postupak koji se vodio po privatnoj tužbi suca Općinskog suda protiv novinara zbog počinjenja kaznenog djela klevete. Konkretno, u spornom članku novinar je napisao kako je tužitelj postao predsjednikom suda u Crikvenici na temelju nepravilnog i nezakonitog suđenja na utakmici u kojoj je igrao NK Dinamo.

23 Hauschildt protiv Danske, zahtjev br. 10486/83, od 24. svibnja 1989. (§ 46).

24 Kodeks časti hrvatskih novinara, dostupno na https://www.google.com/search?q=kodeks+\%C4\% 8Dasti+hrvatskih+novinara\&oq=kodeks+\%C4\%8Dasti+\&aqs=chrome.0.69i59j69i57.3995j0j4\&sourcei $\mathrm{d}=$ chrome \&ie=UTF-8\#, pristupljeno 15. kolovoza 2021. 
U članku se navodi da je tužitelju, sucu i predsjedniku Općinskog suda u Crikvenici (koji je u vrijeme pisanja i objave spornog članka bio i nogometni sudac Prve hrvatske nogometne lige), tadašnji dopredsjednik NK Dinamo preko predsjednika Županijskog suda u Zagrebu pomogao da nakon poništavanja natječaja bude imenovan predsjednikom Općinskog suda u Crikvenici, što predstavlja negativne i nepovoljne činjenične tvrdnje koje su u svakom slučaju mogle naškoditi časti i ugledu privatnog tužitelja, i kao nogometnog suca, i kao pravosudnog dužnosnika.

Analizirajući navode privatnog tužitelja, Općinski je sud ${ }^{25}$ ocijenio kako iznesene činjenične tvrdnje doista predstavljaju neistinite činjenice, što je privatni tužitelj i dokazao, a okrivljenik priznao u svojoj obrani. Međutim, sud je smatrao da privatni tužitelj nije dokazao i ostala obilježja kaznenog djela klevete, konkretno izravnu namjeru okrivljenika, te je ocijenio da su ostvarena obilježja kaznenog djela teškog sramoćenja iz čl. 148. st. 2. Kaznenog zakona ${ }^{26}$ za počinjenje kojeg je okrivljenika oglasio krivim.

Ono što posebno valja istaknuti jest kako sud, u obrazloženju osuđujuće presude (doduše za blaže kazneno djelo, koje je u međuvremenu i brisano iz kataloga inkriminacija propisanih Kaznenim zakonom), u konkretnom slučaju ne posvećuje odveć pažnje činjenici da se radi o sucu i predsjedniku suda, pa da bi se u tom smislu, kroz pružanje zaštite privatnom tužitelju kao pojedincu indirektno pružila zaštita autoritetu sudbene vlasti u cjelini. Navedeno, u formalnom smislu nije pogrešno, niti se radi o propisanoj kvalifikatornoj okolnosti. Međutim, sud ne bi izašao iz ustavom i zakonom propisanog okvira svog djelovanja da je, ocjenjujući značaj postupanja okrivljenika uzimajući u obzir sve okolnosti počinjenja djela, dao jasniji i konkretniji značaj okolnosti da pružanjem zaštite privatnom tužitelju kao sucu šalje vrlo određenu poruku čitavom društvu koja se odnosi na dužnost i nužnost očuvanja autoriteta svakog pojedinog suca i sudbene vlasti u cjelini kako bi se očuvala fukcionalnost čitavog sustava.

Nadalje, treba spomenuti i presudu Općinskog građanskog suda u Zagrebu ${ }^{27}$ gdje je tužitelj, kao sudac Općinskog kaznenog suda u Zagrebu, donio pravomoćnu presudu kojom je Zdravko Mamić (bivši dopredsjednik NK Dinamo) oslobođen optužbe da je izjavom koju je dao na Radiju Soundset u odnosu na Željka Jovanovića (bivšeg ministra u vladi RH) javno poticao na nasilje i mržnju. Naknadno je tuženik, kao nakladnik Samostalnog srpskog tjednika Novosti, objavio članak pod naslovom „Zagrebački Lozina“, koji je objavljen i u elektroničkom izdanju istog tjednika te na internetskoj stranici čiji je nakladnik također tuženik, kao i dva naknadna slična članka iz čijeg je sadržaja razvidno da se autor obračunava i polemizira s tužiteljem nazivajući ga ,pravosudnim junakom“ ili „,ne baš časnim sucem Krešićem“.

25 Presuda Općinskog kaznenog suda u Zagrebu br. K-281/14 od 12. srpnja 2016. koja je potvrđena presudom Županijskog suda u Bjelovaru br. Kž-222/2016 od 13. listopada 2016.

26 Kazneni zakon, NN 125/2011.

27 Br. P-755/14 od 26. ožujka 2015. koja je potvrđena presudom Županijskog suda u Zagrebu br. Gž-3690/15 od 13. veljače 2018 . 
Tužitelj je smatrao da mu je objavom spornog članka povrijeđeno pravo osobnosti, odnosno pravo na duševno zdravlje, ugled, čast, dostojanstvo i ime, ističući da je sudac Općinskog kaznenog suda u Zagrebu, te da je presudu koja je poslužila autoru kao izravni povod za objavu spornog članka, donio u ime Republike Hrvatske, a ne u namjeri da njome promiče svoje osobne stavove o pripadnicima srpske nacionalne manjine u RH. Navedeno pojašnjava činjenicom da povreda ugleda sudaca nije samo povreda ugleda fizičke osobe koja obavlja sudačku dužnost, već se takvim objavama ruši ugled i autoritet sudbene vlasti u cjelini, a dodatno slabi i povjerenje građana u pravosudni sustav. S druge strane, tuženik je, osporavajući navode tužitelja, među ostalim istaknuo da je sporni tekst objavljen u javnom interesu, jer je dužnost medija prenijeti informacije od javnog interesa, te je novinar u konkretnom slučaju iznio svoju vrijednosnu prosudbu o događaju od javnog interesa.

Općinski građanski sud u Zagrebu utvrdio je da je autor članka propustio izvršiti svoju obvezu koja se odnosi na provjeru točnosti informacija koje je iznio u svom članku s obzirom na to da se uopće nije bavio činjenicom iz kojeg je razloga predmetna presuda donesena na način da je optužba odbijena. Autor članka je, bez ikakve provjere podataka, u smislu razloga zbog kojih je presuda donesena, napisao članak kao komentar navedene presude pri čemu je iznio uvredljiv i netočan sadržaj u odnosu na tužitelja, te je time postupio suprotno čl. 5. i 6. Kodeksa časti hrvatskih novinara.

Konačno je sud utvrdio da ne postoji niti jedan ekskulpirajući razlog iz čl. 21. st. 4. Zakona o medijima ${ }^{28}$ u smislu da se radi o informaciji koja je proizašla iz vrijednosnog suda autora čije je objavljivanje bilo u javnom interesu i ako je ta informacija dana u dobroj vjeri jer je iz naprijed navedenih razloga utvrđeno da postupanje tuženika nije bilo u dobroj vjeri.

Proizlazi, dakle, da je sud uzeo u obzir činjenicu da je tužitelj sudac Općinskog kaznenog suda u Zagrebu kojem je, sukladno poslu koji obavlja, vrlo važno na koji način ljudi oko njega procjenjuju njegov moralni integritet. Smatramo ipak da je bilo prostora da se u obrazloženju presude i dodatno obrazloži važnost te činjenice koja nadilazi osobni kontekst na koji ju je sud sveo, imajući u vidu da se presude donose u ime Republike Hrvatske, koja je pak u obvezi pružiti sucima odgovarajuću zaštitu kako bi mogli u okviru autoriteta državne vlasti, čiji su dio, donositi nepristrane odluke o pravima i obvezama građana.

Valja naglasiti kako je uloga suda uspostaviti ravnotežu između časti suca i slobode novinara u izvještavanju o pitanjima od javnog interesa te odlučiti što je prioritet u demokratskom društvu. Sudovi su, kod donošenja odluke, imali u vidu oba elementa ključna prilikom odmjeravanja ravnoteže odnosno interesa: doprinos javnoj raspravi (što je veći, veći je i prostor za kritiku) kao i razinu i način kritike sudačkog djelovanja.

28 Zakon o medijima, pročišćeni tekst, NN br. 59/04, 84/11, 81/13. 


\subsection{Očuvanje autoriteta i nepristranosti sudbene vlasti - praksa Ustavnog suda RH}

Nakon ovih dvaju primjera iz prakse općinskih sudova koji daju uvid i u kaznenopravni i u građanskopravni aspekt postupanja gdje je tuženik/okrivljenik novinar, i iz kojih možemo zaključiti da se u određenom smislu, ali ne na način da bi ta okolnost bila detaljnjije razrađena, uzima u obzir zanimanje privatnog tužitelja/ tužitelja, te radi distinkcija u narušavanju ugleda svake osobe u odnosu na osobu koja je i sudac, osvrnut ćemo se i na praksu Ustavnog suda i to na one odluke u kojima su podnositelji ustavne tužbe bili odvjetnici, a deriviraju iz predmeta u kojima su njihovi istupi u obavljanju odvjetničke službe i zastupanju stranaka od strane sudova bili ocjenjivani vezano za dužnost poštovanja suda. Pri navedenom važno je podsjetiti da je način pružanja pravne pomoći propisan čl. 7. Zakona o odvjetništvu ${ }^{29}$ kojim se upućuje na primjenu pravila Kodeksa odvjetničke etike ${ }^{30}$ koji se u glavi VIII. (pravila 85 do 99) bavi odnosom odvjetnika prema sudovima, propisujući prvenstveno da u obavljanju svoga poziva odvjetnik, kao suradnik suda u ostvarivanju u bitnome iste zadaće, mora uvijek čuvati autoritet sudova pred kojima pruža pravnu pomoć, te im uvijek iskazivati dužno poštovanje, suzdržavajući se od uvredljivih izjava ili omalovažavajućih mišljenja o njihovim odlukama, lakoumnog i nepromišljenog traženja izuzeća sudaca, optuživanja i slično, uvijek upućujući i svoje stranke na dužno poštovanje prema sudovima. Konačno, prikazat će se i jedna odluka Ustavnog suda u predmetu u kojem je novinar u procesnoj ulozi podnositelja ustavne tužbe.

Prije svega, valja spomenuti odluku br. U-III/63/2017 od 26. veljače 2019., u kojoj je Ustavni sud, suprotno svojoj ranijoj praksi, ${ }^{31}$ prihvatio pravna stajališta ESLJP-a u pogledu pravne prirode odluka sudova kojima su strankama, umješačima i njihovim punomoćnicima u sudskom postupku izrečene novčane kazne zbog zlouporabe prava što im u sudskom postupku pripadaju ili zbog vrijeđanja suda, u pogledu karaktera i dosega instituta slobode izražavanja, te kruga osoba koje potpadaju pod domašaj te slobode, kao i prava države da ograniči slobodu izražavanja, te je promijenivši svoje dosadašnje tumačenje pravne prirode navedenih odluka utvrdio da su one pojedinačni akti u smislu čl. 62. st. 1. Ustavnog zakona o ustavnom sudu RH.

U konkretnoj pravnoj stvari, podnositeljima je izrečena novčana kazna zbog vrijeđanja suda. Pri tome se ocjena prvostupanjskog suda o počinjenom vrijeđanju temelji na tvrdnjama podnositelja iznesenima u predstavci (nazvanoj pritužba) na rad nadležnog suca, podnesenoj Vrhovnom sudu. Ustavni sud utvrdio je da izricanje novčane kazne podnositeljima predstavlja miješanje u njihovu slobodu izražavanja

29 Zakon o odvjetništvu, NN br. 09/94, 117/08, 50/09, 75/09, 18/11.

30 Kodeks odvjetničke etike, NN br. 64/07, 72/08 i 64/18.

31 U rješenjima br.U-III-3285/2002 od 28. ožujka 2003., br. U-III-231/2003 od 28. ožujka 2003. te br.U-III-4772/2004 od 25. veljače 2005. i drugima u kojima je iznosio shvaćanje prema kojem odluke sudova kojima su strankama, umješačima ili njihovim punomoćnicima izrečene novčane kazne zbog zlouporabe prava koja im u sudskom postupku pripadaju ili zbog vrijeđanja suda nisu pojedinačni akti u smislu čl. 62. st. 1. Ustavnog zakona o Ustavnom sudu Republike Hrvatske (pročišćeni tekst, NN br. 99/99, 29/02, 49/02). 
zajamčenu člankom 38. Ustava. Nadalje, Ustavni je sud ocijenio da predstavka (pritužba) podnositelja sadržajno ne predstavlja podnesak upućen raspravnom sudu, nego tek korištenje prava stranke na slanje predstavki i pritužbi. ${ }^{32}$ Stoga, raspravni sud nije ovlašten sankcionirati stranku zbog izraza i navoda uporabljenih u predstavci (pritužbi) upućenoj višem sudu. Slijedom navedenog, Ustavni je sud utvrdio da miješanje u slobodu izražavanja podnositelja nije utemeljeno na zakonu te da je osporenim odlukama podnositeljima povrijeđeno jamstvo slobode mišljenja i izražavanja misli u vezi s pravom na slanje predstavki i pritužbi zajamčenim čl. 46. Ustava. Ovo je jedan od rijetkih primjera gdje je utvrđena povreda prava na slobodu izražavanja zbog izostanka adekvatne zakonske regulative koja bi tu slobodu ograničavala, iz kojeg razloga nije bilo potrebno ispitivati nužnost ni razmjernost miješanja.

Nadalje, odlukom br. U-III/3373/2018 od 10. srpnja 2019., u pogledu Ustavne tužbe podnesene u povodu rješenja Visokog trgovačkog suda Republike Hrvatske broj: Pž-3075/2018-2 od 13. srpnja 2018. (drugostupanjsko rješenje) i rješenja Trgovačkog suda u Rijeci broj: P-408/2017-39 od 23. travnja 2018. (prvostupanjsko rješenje) kojim je odbijena žalba podnositelja (osporavatelja u postupku utvrđivanja osnovanosti tražbine) utvrđeno je kako nema povrede prava na slobodu izražavanja odvjetnika.

Prema ocjeni Ustavnog suda, navodi koje je podnositelj iznio na pripremnom ročištu predstavljaju ozbiljne tvrdnje kojima se na izravan način osporava sposobnost suda da na zakonit, nepristran, objektivan i stručan način riješi konkretan spor. Ustavni sud također je primijetio da je podnositelj, tijekom postupka, podnio zahtjev za izuzeće sutkinje koji je odbijen kao neosnovan. U odnosu na tvrdnje podnositelja da je sud na neki način uključen u ,zločinački pothvat i pljačku imovine Republike Hrvatske“, Ustavni je sud utvrdio da one nisu ničim potkrijepljene te da podnositelj ima na raspolaganju druga pravna sredstva izvan konkretnog postupka u kojima se ispituju ozbiljnosti njegovih tvrdnji. Sukladno navedenom, iznesene tvrdnje predstavljaju izravno omalovažavanje autoriteta suda i usmjerene su prema onemogućavanju suda u upravljanju i vođenju sudskog postupka na kontroliran i uredan način.

U navedenoj odluci Ustavni se sud pozivao na shvaćanja ESLJP-a iz predmeta Radobuljac protiv Hrvatske, ${ }^{33}$ kao i na svoju Odluku U-III/63/2017 od 26. veljače 2019., te ocijenio da su sudovi, čije odluke podnositelj osporava kao nepravično ograničenje svoje Ustavom zajamčene slobode izražavanja, obrazložili svoja stajališta ozbiljnim, dostatnim i relevantnim razlozima o utvrđenju da je podnositelj neprimjerenom komunikacijom vrijeđao sud te opravdanost udaljavanja podnositelja s ročišta i izricanja novčane kazne radi sprečavanja daljnjeg ometanja rada suda.

32 Zajamčenog člankom 46. Ustava i propisanog čl. 4. st. 3. Zakona o sudovima, NN br. 28/13-67/18. Takva predstavka (pritužba) po prirodi stvari nije dio parničnog postupka i zato nije u dosegu članka 110. Zakona o parničnom postupku, NN br. 53/91-89/14.

33 Radobuljac protiv Hrvatske, zahtjev br. 51000/11, od 28. lipnja 2016. 
Osporenim odlukama podnositelju stoga nije povrijeđeno ustavno pravo na slobodu izražavanja.

Također, i u recenetnoj odluci br. U-III/3675/2018 od 15. siječnja 2020. Ustavni je sud odbio ustavnu tužbu podnositelja, pozivom na odredbe čl. 16. i 38. Ustava. Naime, u konkretnom slučaju, uređujući sudac prvostupanjskog suda ocijenio je da ponašanje podnositelja - koji je na glavnoj raspravi održanoj u predmetnom postupku, neovlaštenim tonskim snimanjem tijeka rasprave zlouporabio prava koja mu kao stranci u postupku (umješaču na strani tužitelja) pripadaju, te osobito u nastavku kada je te tonske zapise, kojima je izostala provjera autentičnosti i s te osnove vjerodostojnosti (jer nisu suglasni službeno sačinjenom zapisniku o tijeku i radnjama provedenim na prijepornoj glavnoj raspravi) učinio javno dostupnim na internetskom portalu - nije u skladu s civiliziranom komunikacijom koja se očekuje u ophođenju stranke u odnosu na sud. U konačnici podnositelj je i izborom riječi kojima se poslužio poslije u podnesenom pravnom lijeku (žalbi), kojom prilikom je uređujućeg suca prvostupanjskog suda „prozvao za kriminal i nezakonit rad“, prešao granicu civiliziranog i korektnog ophođenja stranke prema sudu. S navedenim se složio i Ustavni sud i odbio ustavnu tužbu, zaključivši kako su sudovi svoja izražena stajališta obrazložili dostatnim i relevantnim razlozima utvrdivši neprimjereno ponašanja podnositelja kao zlouporabu prava koju je iskazao neovlaštenim tonskim snimanjem tijeka glavne rasprave, te u konačnici i uvredljive kritike rada suca što ju je iznio u sadržaju žalbe.

Konačno, treba spomenuti odluku Ustavnog suda br. U-III/2886/2011. od 1. lipnja 2016. gdje je tužbu podnio novinar, odnosno nakladnik s obzirom na to da je u postupku, koji je prethodio ustavnosudskom, predmet spora bio zahtjev tužitelja/suca Vrhovnog suda za naknadu neimovinske štete u vidu duševnih boli zbog povrede prava osobnosti, prouzročenih objavom članaka u Jutarnjem listu pod naslovom „Sudac Vrhovnog suda izdao lažni dokument“" od 3. studenoga 2008. i pod naslovom „Miroslav Sovanj - sudac ilegalno u gradskom stanu“ od 23. studenoga 2008., oba članka autora Drage Hedla. Prvostupanjski je sud odlučivao o osnovanosti zahtjeva za svaki članak pojedinačno, te za prvospomenuti članak utvrdio da je tužitelj zbog objavljenog članka pretrpio neimovinsku štetu u vidu duševne boli zbog povrede prava osobnosti. ${ }^{34}$

Iz obrazloženja prvostupanjske presude u bitnome proizlazi kako postojanje javnog interesa za osobe koje obnašaju jedan tako častan poziv kao što je sudac Vrhovnog suda Republike Hrvatske, ne isključuje obvezu novinara podastrijeti sve istinite i potpune informacije o radu tog suca. U konkretnom slučaju, sud je stava da je to izostalo, jer tuženik očito nije imao namjeru obavijestiti javnost da je sudac proveo zakoniti postupak već javnosti podastrijeti nepotpune informacije u cilju diskreditiranja tužitelja kao osobe i suca (\$ 2.1.) S navedenim stajalištem složio

34 U odnosu na osnovanost zahtjeva za naknadu štete za članak pod naslovom „Miroslav Šovanj - sudac ilegalno u gradskom stanu“, prvostupanjski je sud utvrdio da su ispunjene pretpostavke za oslobođenje podnositelja od odgovornosti na temelju čl. 21. st. 4. Zakona o medijima s obzirom na to da su informacije vezane uz navedeni članak pribavljene od nadležnih državnih institucija i autor članka poduzeo je sve potrebne mjere za provjeru njihove točnosti te su informacije bile točne. 
se i Ustavni sud te ocijenio da su sudovi valjano obrazložili svoje stajalište, te da podnositelju nije povrijeđeno pravo na slobodu izražavanja.

Za zaključiti je da ako javnost i ima pravo znati, onda s jedne strane novinarski tekst bez sadržaja na koje su sudovi ukazali suštinski zadire u pravo javnosti da zna, dok s druge strane upravo objavljivanje teksta bez tih sadržaja ne predstavlja nikakav doprinos raspravi od javnog interesa.

\subsection{Očuvanje autoriteta i nepristranosti sudbene vlasti - praksa Europskog suda za ljudska prava}

Okrećući se praksi ESLJP-a i to u odnosu na zaštitu tj. ograničenje slobode izražavanja kako odvjetnika u sudnici i odvjetnika izvan sudnice tako i novinara, treba naglasiti kako, prvo, sloboda izražavanja stranaka u sudnici nije neograničena i određeni interesi, kao što je autoritet sudbene vlasti, dovoljno su važni da opravdavaju ograničenja ove slobode. Nadalje, sloboda novinarskog izvještavanja, iako uživa široku zaštitu, također, u slučajevima potrebe za očuvanjem nepristranosti i autoriteta sudačke vlasti, može i treba biti ograničena.

Prvi predmet u kojemu se pojavilo pitanje očuvanja nepristranosti i autoriteta sudbene vlasti jest Sunday Times protiv Ujedinjenog Kraljevstva iz 1979. U konkretnom predmetu radilo se o zabrani novinskog izvještavanja predmeta koji je još bio u tijeku pred nacionalnim sudovima, što je britanska vlada opravdavala interesom zaštite nepristranosti sudstva i očuvanja povjerenja javnosti u sudske organe. S obzirom na opće kriterije, Sud je utvrdio kako je navedeno pitanje, kao i informiranje javnosti o okolnostima ovog slučaja od nespornog javnog značaja (radilo se o rođenju djece s teškim deformitetom izazvanim lijekovima koje su trudnice koristile) te kako sudska zabrana izdana protiv novina ne odgovara društvenoj potrebi koja je u dovoljnoj mjeri goruća da prevagne nad javnim interesom slobode izražavanja u smislu Konvencije (\$ 67).

S druge strane, u predmetu De Haes i Gijsels protiv Belgije ${ }^{35}$ podnositelji zahtjeva bila su dvojica novinara koji su optužili belgijskog bilježnika za zlostavljanje djece; a kada su belgijski sudovi odlučili osloboditi javnog bilježnika, ta dvojica novinara počela su napadati suce koji su ocu dodijelili skrbništvo nad djecom za pristranost, povezanost s ekstremno desničarskim skupinama i opstruiranje pravde. S obzirom na napisano u člancima, suci su podnijeli tužbu za klevetu protiv navedenih novinara. Prizivni sud u Bruxellesu osudio je dvojicu novinara plaćanjem, zbog klevete, simboličan iznos od 1 belgijskog franka svakom sucu. Suprotno belgijskim sudovima, ESLJP je smatrao da su se novinari u prilog svojih zahtjeva oslanjali na detaljne činjenične podatke i da nisu kršili svoje profesionalne obveze. Prema ESLJP-u, optužbe novinara iznosile su mišljenje i vrijednosne sudove, što nije bilo pretjerano, već proporcionalno uznemirenju i ogorčenju izazvanim pitanjima navedenim u njihovim člancima. Dajući odgovarajući značaj pravu javnosti da bude

35 De Haes i Gijsels protiv Belgije, zahtjev br. 19983/92, od 24. veljače 1997. 
informirana o pitanju od javnog interesa, Sud je odlučio da odluka domaćih sudova nije bila neophodna u demokratskom društvu i da je, shodno tome, došlo do povrede čl. 10. no valja naglasiti kako ista nije donesena jednoglasno.

Zanimljivo je ovaj predmet promatrati kroz prizmu supra analiziranih odluka gdje su domaći sudovi, koristeći iste argumente, ipak utvrdili kako novinaru/ nakladniku nije povrijeđeno pravo na slobodu izražavanja, prvenstveno iz razloga što je svoje navode temeljio na vrijednosnim sudovima, a ne na provjerenim činjeničnim osnovama prilikom javnog kritiziranja rada sudaca.

Evidentno je kako se u predmetima u kojima suci optužuju novinare za klevetu radi o situacijama u kojima odlučujući suci moraju uspostaviti ravnotežu između časti predmetnog suca i slobode novinara da izvještavaju o pitanjima od javnog interesa te u svakom pojedinom slučaju odlučiti što je prioritet u demokratskom društvu. Čini se da su dva elementa ključna prilikom odmjeravanja ravnoteže odnosno interesa: doprinos javnoj raspravi (što je veći, veći je i prostor za kritiku) kao i razina i način kritike sudačkog djelovanja. Još jedno važno pitanje u ovom dijelu jest mogućnost javnog osporavanja pravomoćnih sudskih odluka. Ovim predmetima bavit ćemo se infra i to nakon prikaza prakse Suda u predmetima u kojima su podnositelji bili odvjetnici.

Naime, glede kritike koju odvjetnici upućuju sucima, postojeća pravila koja se odnose na ograničenje klevetničkog govora po osnovi čuvanja autoriteta i nepristranosti sudstva, u donekle su drukčijoj situaciji. U navedenim predmetima razlikujemo dva konteksta u kojima se kritika upućuje - kritike upućene u sudnici te kritike upućene putem medija. Navedeno je moguće prikazati upravo putem dvaju ključnih predmeta: Nikula protiv Finske ${ }^{36}$ gdje su kritike upućene u sudnici i Morice protiv Francuske ${ }^{37}$ gdje su kritike upućene putem medija.

U predmetu Nikula, podnositeljica zahtjeva kritizirala je državnog odvjetnika, gospodina T. zbog „manipulacije funkcije i nezakonitog izvođenja dokaza“. Po privatnoj tužbi koju je podnio g. T., gđa Nikula je 1994. godine osuđena zbog klevete te je Vrhovni sud potvrdio kaznenu presudu 1996. godine, no ograničio sankciju samo na plaćanje naknade štete i troškova. ESLJP je u navedenom predmetu utvrdio povredu prava podnositeljice naglasivši kako samo u izuzetnim slučajevima ograničenje slobode izražavanja pravnog zastupnika obrane može biti prihvaćeno kao neophodno u demokratskom društvu, dok u konkretnom predmetu nužnost nije postojala. Naime, Sud je stajališta kako, u interesu nesmetanog rada pravosudnog sustava, disciplinska tijela koja kažnjavaju određeno ponašanje odvjetnika moraju osigurati da iste ne predstavljaju prijetnju sa chilling učinkom kojom bi se naštetilo obrani interesa njihovih branjenika. ${ }^{38}$ Sud je naglasio kako su podnesci podnositeljice zahtjeva bili ograničeni na sudnicu, za razliku od kritika na

36 Nikula protiv Finske, zahtjev br. 31611/96, od 21. ožujka 2002.

37 Morice protiv Francuske, zahtjev br. 29369/10, od 23. travnja 2015. (VV).

38 Vidi također Bono protiv Francuske, zahtjev br. 29024/11, od 15. prosinca 2015., § 55; Kyprianou protiv Cipra, zahtjev br. 73797/01, od 15. prosinca 2005. (VV), § 181; Rodriguez Ravelo protiv Śpanjolske, zahtjev br. 48074/10, od 12. siječnja 2016., § 49. 
račun suca ili tužitelja izrečenih u, primjerice, medijima te kako ne može utvrditi da je podnositeljičina kritika tužitelja, imajući procesni karakter, predstavljala osobnu uvredu. Konačno, zaključio je Sud kako se samo u iznimnim slučajevima ograničenje - čak i blažom kaznom - slobode izražavanja branitelja može prihvatiti kao neophodno u demokratskom društvu. Stoga se bez dvojbe može zaključiti kako je upravo u predmetu Nikula uspostavljena sloboda branitelja kritizirati određena ponašanja u sudnici, u funkciji obrane svog branjenika.

S druge strane, predmet Morice odnosio se na izjave koje je odvjetnik/podnositelj zahtjeva dao u francuskom dnevnom listu Le Monde; izjave su sadržale tekst pisma koje je podnositelj zahtjeva poslao ministru pravosuđa, tražeći da se pokrene upravna istraga protiv dvojice sudaca istrage. $\mathrm{U}$ konkretnom predmetu radilo se o istrazi ubojstva poznatog francuskog suca gdje je podnositelj zahtjeva osporavao i kritizirao rad sudaca istrage. Navedeni suci podnijeli su kaznenu prijavu protiv direktora sektora za izdavaštvo časopisa Le Monde, novinara koji je napisao članak i g. Moricea, optužujući ih za kazneno djelo javne klevete državnog službenika. G. Morice je na kraju proglašen krivim za supočiniteljstvo u tom djelu od strane žalbenog suda, dok je Vrhovni sud odbio žalbu zbog pogrešno/nepotpuno utvrđenog činjeničnog stanja.

U zahtjevu pred ESLJP-om, g. Morice pozivao se na pravo odvjetnika da u okviru obrane svojih branjenika daju i izjave za medije. Valja ponovno naglasiti kako je, prema tvrdnjama Suda, u pogledu statusa i slobode izražavanja odvjetnika bilo neophodno napraviti jasnu razliku između riječi koje je odvjetnik izgovorio unutar i riječi koje je izgovorio izvan sudnice. U svojoj presudi Vijeće je kritiku koju je izrekao g. Morice ocijenilo posebno oštrom, a optužbe vrlo ozbiljnima te je smatralo je da je g. Morice prekoračio granice koje bi odvjetnici morali poštovati javno kritizirajući pravosudni sustav. Na zahtjev g. Moricea, predmet je upućen Velikom vijeću.

Veliko vijeće je, praveći jasnu razliku između novinara i odvjetnika te naglašavajući kako se njihova mjesta $\mathrm{i}$ uloge u sudskim postupcima suštinski razlikuju, glede odvjetnika naglasio kako kada se radi o riječima izgovorenim izvan sudnice, odvjetnici moraju izbjegavati riječi koje se svode na bezrazložan osobni napad bez neposredne veze s predmetnim činjeničnim supstratom. S obzirom na navedeno, u ovom predmetu suci nisu vidjeli na koji način su izjave g. Moricea mogle neposredno doprinijeti njegovoj dužnosti da brani svog branjenika, budući da je sudska istraga do tog trenutka bila povjerena jednom drugom sucu. Međutim, nakon što su odbacili ideju da je g. Morice intervenirao kao odvjetnik u kontekstu obrane okrivljenika, naglasili su da su njegove izjave dio rasprave o stvari od javnog interesa (s obzirom na to da su se odnosile na funkcioniranje ili na navodne nedostatke) pravosudnog sustava ( $§ 150$ i dalje).

Sukladno tome, postojanje „rasprave o pitanju od javnog interesa“ u ovom slučaju opravdava viši stupanj zaštite slobode izražavanja (a time i vlasti imaju uže polje slobodne procjene - u ograničavanju takve slobode) te je Veliko vijeće utvrdilo da u konkretnom predmetu izjave podnositelja, iako su predstavljale vrijednosne sudove, 
nisu neopravdano vrijeđale, već su imale uporište u dostatnoj činjeničnoj osnovi. Veliko je vijeće također primijetilo da osuda podnositelja zahtjeva nije pridonijela ni na koji način zaštiti sudstva, naglasivši važnost održavanja autoriteta pravosuđa i osiguranja odnosa koji se temelje na uzajamnom razmatranju i poštovanju između raznih protagonista pravosudnog sustava. Dakle, unatoč ograničenom stupnju zaštite koji odvjetnici uživaju prilikom javnog kritiziranja sudske vlasti, ako oni to čine na općenitoj razini, u pitanjima od javnog interesa, možemo reći kako uživaju stupanj zaštite gotovo identičan onome koji uživaju novinari prilikom iznošenja vrijednosnih sudova, koji ipak imaju činjenični temelj.

\subsection{Očuvanje autoriteta i nepristranosti sudbene vlasti - hrvatski predmeti pred Europskim sudom za ljudska prava}

\subsubsection{Odvjetnici kao podnositelji zahtjeva}

Konačno, i pred ESLJP-om se našlo nekoliko predmeta protiv Republike Hrvatske u ulozi tuženika, a odnose se na očuvanje autoriteta i nepristranosti sudačke vlasti. Prije svega valja spomenuti presudu u predmetu Žugić protiv Hrvatske, ${ }^{39}$ gdje je utvrđeno kako nije došlo do povrede članka 10. Konvencije sankcioniranjem podnositelja zbog vrijeđanja suda. Predmet je zanimljiv i po tome što je Prvi odjel Europskog suda presudu donio tijesnom većinom, jer su tri od sedam sudaca glasala protiv odluke, što su obrazložila u svojim izdvojenim mišljenjima. Konkretno, podnositelj zahtjeva smatrao je kako je izricanje novčane kazne zbog uvrede suda, koju on u danim okolnostima smatra nepravednom, povrijedilo njegova prava iz 10. Konvencije. Naime, nakon što je zaprimljena žalba podnositelja protiv rješenja o ovrsi, uređujuća sutkinja prvostupanjskog suda ocijenila je da je podnositelj u žalbi vrijeđao sud te donijela odluku kojom ga novčano kažnjava. ${ }^{40}$ Podnositelj zahtjeva izjavio je žalbu protiv te odluke tvrdeći, inter alia, da je prvostupanjski sud proizvoljno tumačio njegove izjave, da one nisu bile uvredljive i da on nije imao nikakvu namjeru bilo koga uvrijediti. Drugostupanjski sud odbio je žalbu podnositelja zahtjeva i potvrdio prvostupanjsku odluku. Nakon što je i Ustavni sud odbio njegovu tužbu, podnositelj se obratio i ESLJP-u koji je utvrdio da nije došlo do povrede članka 10 . Konvencije, ${ }^{22}$ što je obrazloženo težnjom za ostvarenjem legitimnog cilja održavanja autoriteta sudbene vlasti u smislu čl. 10. st. 2. Konvencije s jedne strane i činjenicom da je, prema mišljenju većine, postignuta pravedna ravnoteža između potrebe da se zaštiti autoritet sudbene vlasti i zaštite slobode izražavanja podnositelja zahtjeva. Naime, većina je stajališta kako u ovom predmetu pobijane izjave, izrečene na omalovažavajući i drzak način, nisu bile

39 Žugić protiv Hrvatske, zahtjev, br. 3699/08, 31. svibnja 2011.

40 Između ostalog, podnositelj je napisao: „Indikativno je ovdje napomenuti da je sutkinja, prije diktata izreke presude, upitala tuženog hoće li „ovo platiti”, a na što je tuženik odgovorio „što Vam pada na pamet?" i je li ona proučila spis... Sutkinja se ljutito okrenula sa stolice na bok i zapisničarki izdiktirala izreku presude u ime RH, navodeći komičan izraz da stranke traže obrazloženje presude - kao da u kontradiktornom postupku postoje presude bez obrazloženja ili bez pouke o pravnom lijeku. Nažalost, ove dijaloge sutkinje i tuženoga, sud nije unio u zapisnik. Kakva li je ovo sudačka profesionalnost!" (\$ 7) 
samo kritika prvostupanjske presude i načina na koji je sutkinja vodila postupak, nego su, kao što su smatrali i domaći sudovi, podrazumijevale i da je ona neznalica i nesposobna (§ 47).

Tu svakako treba spomenuti i izdvojeno mišljenje troje sudaca u kojem je izraženo neslaganje s mišljenjem većine da nije bilo povrede članka 10. Konvencije, za što su, u bitnom, dani ovi razlozi: ništa u izričaju žalbe nije išlo preko prihvatljivih granica; navedena sudska praksa tiče se slučajeva kad su izjave podnositelja zahtjeva bile jako uvredljive (poput „mučitelji u sudskim odorama“); u ovom predmetu podnositelj zahtjeva samo je opisao, iako snažnim riječima, što se događalo na raspravi; ocjena mjerodavnih činjenica nije prihvatljiva; izjave podnositelja zahtjeva u njegovoj žalbi nisu uvredljive i stoga razlozi koje su dali domaći sudovi u potporu svojih odluka nisu „mjerodavni i dostatni“.

Tijesna većina kojom je donesena odluka o nepostojanju povrede ukazuje na velike mogućnosti koje su ostavljene sucima prilikom odlučivanja je li prekoračena granica dopuštene kritike sudske vlasti, odnosno prilikom odlučivanja je li podnositelj prešao granice dopuštene kritike, $i$ to unutar sudnice. Posebno je znakovito što $u$ konkretnom predmetu Sud nije utvrdio povredu čl. 10 podnositelju iako je kritizirao rad suda unutar sudnice i to u postupku u kojem je sam sebe zastupao, dakle branio je vlastite interese te se možemo čak i složiti s mišljenjem manjine kako nije koristio uvrdljive izraze već samo „snažne“ riječi.

Istodobno, možemo reći kako presuda u predmetu Žugić predstavlja svojevrsnu nedosljednost Suda, odnosno odstupanje Suda od postojeće prakse. Naime, stav je Suda kako suci - osim u slučaju ozbiljno štetnih napada koji su u osnovi neutemeljeni - imajući na umu da suci čine dio temeljne državne institucije, mogu kao takvi biti predmet osobne kritike u dopuštenim granicama, i to ne samo u teoriji i uopćeno. Stoga, kada djeluju u službenom svojstvu šire su granice prihvatljive kritike nego prema običnim građana (Bychawska-Siniarska, 2017., str. 83-84). ${ }^{41}$ Nadalje, Sud smatra kako treba razlikovati situacije ovisno o tome izražava li se odvjetnik u sudnici ili negdje drugdje (javno), iako i javno uživa široku slobodu kritiziranja sudaca ako ukazuje na problem odnosno na pitanje od javnog interesa (v. supra predmet Morice). Odvjetnici su dužni „revno braniti interese svojih klijenata“, što znači da ponekad moraju odlučiti trebaju li prigovarati ili se žaliti o ponašanju suda. Uz to, Sud uzima u obzir činjenicu da se osporene izjave ne ponavljaju izvan sudnice (Bychawska-Siniarska, 2017., str. 84). Stoga ostaje nejasna odluka Suda u predmetu Zugić.

Ovakvo odstupanje od svojih stajališta Sud je ispravio u sljedećoj presudi protiv RH, Radobuljac protiv Hrvatske gdje se također pojavilo pitanje prekoračenja slobode govora unutar sudnice. Naime, Europski sud u konkretnom je predmetu utvrdio da je Općinski sud u Vukovaru svojom presudom povrijedio pravo tužitelja na slobodu govora, naglasivši kako je tužitelj kao odvjetnik sudjelovao u postupku

41 Morice protiv Francuske § 131; July i SARL Libération protiv Francuske, zahtjev br. 20893/03, od 14. veljače 2008., § 74; Aurelian Oprea protiv Rumunjske, zahtjev br. 12138/08, od 19. siječnja 2016. , $\S 74$. 
pred tim sudom, te je tijekom postupka komentirao rad suda na način da je ustvrdio „da se nastoji stvoriti dojam da se postupa u predmetnoj stvari dok se suštinski ročišta održavaju bez smislenog sadržaja“. Europski je sud smatrao kako tužitelj nije prešao granicu dopuštene kritike rada suda, pa da stoga kažnjavanje tužitelja zapravo predstavlja neopravdano miješanje u njegovo pravo na slobodu izražavanja.

Razmatrajući kritike podnositelja, u oba slučaja izrečene unutar sudnice, nije jasno kojim se kriterijima vodio Sud u predmetu Žugić, a kojim u predmetu Radobuljac, izuzev razlike u visini sankcije koja je dosuđena podnositeljima, što, ako je i bio motiv Sudu za donošenje različitih presuda, nije obrazložio niti naveo, a to presudu u tom dijelu čini neispitivom.

Kao što je naglašeno, i sam je Sud stava kako, osim u slučaju teških štetnih napada koji su u osnovi neutemeljeni - imajući na umu da su suci dio temeljne institucije države, kao takvi mogu biti predmet osobne kritike unutar dopuštenih granica, a ne samo na teoretski i općenit način. Stoga, čini se da je moguće s visokim stupnjem vjerojatnosti zaključiti kako praksa Suda u odnosu na kritike upućene sucima unutar sudnice ide u smjeru široke slobode dopuštene kritike, s iznimkom u predmetu Žugić.

\subsubsection{Nakladnici / novinari kao podnositelji zahtjeva}

Kada govorimo o zahtjevima podnesenim protiv RH od strane novinara i nakladnika koji su sankcionirani zbog svojih tekstova, u svrhu zaštite i očuvanja autoriteta i nepristranosti sudačke vlasti, podnesen je samo jedan takav zahtjev od strane novinara odnosno nakladnika, koji ce biti prikazan u ovom radu. No u praksi Suda postoji niz predmeta, počevši od predmeta Sunday Times, u kojima je Sud ispitivao sporno pitanje. Kada govorimo o kriterijima ustanovljenima od strane Suda, oni su jasno definirani, i to su sljedeći: 1. doprinos raspravi od javnog interesa; pitanja koja se tiču funkcioniranja pravosudnog sustava, institucije koja je od ključne važnosti za bilo koje demokratsko društvo spada u javni interes (Morice protiv Francuske, § 128; July i SARL Libération protiv Francuske, § 67), pozivajući tako na visoku razinu zaštite slobode izražavanja, s posebno uskom slobodom procjene vlastima (Morice protiv Francuske, § 125. i 153.; July i SARL Libération protiv Francuske, § 67); 2. priroda ili sadržaj osporenih komentara; 3. način na koji su dobivene osporene informacije; 4 . razmjernost zabrane objavljivanja ili druge sankcije.

Također, u predmetima koji se odnose na medijsko izvještavanje u vezi s pravosudnom djelatnosti, Sud je naglasio nekoliko dodatnih kriterija koji se primjenjuju ovisno o kontekstu: 1. Objavljivanje informacija/izjava koje bi mogle utjecati na tijek sudskog postupka; 2. Objavljivanje informacija koje će vjerojatno dovesti do kršenja tajnosti sudske istrage i pretpostavke nevinosti; 3. Objavljivanje informacija koje se odnose na privatni život stranaka u postupku; te 4. nepoštovanje suda (Guide on Article 10 of the European Convention on Human Rights, Freedom of expression, 2020., str. 83-86). 
Jamstva novinarima propisana čl. 10. Konvencije u vezi s izvještavanjem o pitanjima od javnog interesa, podložna su temeljnoj pretpostavci da novinari postupaju dobronamjerno i etično sa svrhom pružanja točnih i pouzdanih informacija. Pri čemu, kod valorizacije javnog interesa valja imati na umu da taj interes u svakom slučaju mora biti srazmjeran interesu osobe o kojoj se u javnosti piše u izrazito negativnom kontekstu, jer svatko ima pravo da se neutemeljenim i neistinitim tvrdnjama odnosno difamiranjem kroz medije, ne našteti njegovoj časti i ugledu na način da se u javnosti dovede u pitanje zakonitost njegova rada i time bude izložen javnom prijekoru, osudi i preziru.

Bez ulaženja u detalje gore spomenutih kriterija, postupanje Suda prikazat ćemo kroz presudu Narodni list d.d. protiv Hrvatske. ${ }^{42}$ Naime, u tjedniku Narodni list objavljen je članak pod naslovom „Suca B. treba prikovati na stup sramote“, u kojem je kritiziran sudac zbog prisustvovanja otvaranju dnevnih novina kontroverznog lokalnog poduzetnika kao i zbog ranijeg potpisivanja naloga za pretragu prostorija Narodnog lista. Nakon što je tjednik odbio objaviti ispriku, sudac je pokrenuo parnični postupak radi naknade štete zbog povrede prava osobnosti. Domaći sudovi presudili su u njegovu korist i naložili nakladniku Narodnog lista isplatu iznosa od 50.000,00 kuna na ime neimovinske štete. Županijski sud u Splitu odbio je nakladnikovu žalbu, a Ustavni sud ustavnu tužbu slijedom čeka se nakladnik obratio Europskom sudu koji je, ocjenjujući razmjernost odluka domaćih sudova, utvrdio da je miješanje u podnositeljevu slobodu izražavanja (donošenjem presude) bilo propisano domaćim zakonima i težilo legitimnom cilju zaštite ugleda suca, ali nije bilo nužno u demokratskom društvu.

Utvrđujući da se sporni članak odnosio na pitanje od javnog interesa, odnosno na skretanje pozornosti javnosti na način funkcioniranja pravosuđa, Sud je istaknuo da u okviru čl. 10. postoji mali prostor za ograničenja političkog govora ili rasprave o pitanjima od javnog interesa. Drugim riječima, postoji visok stupanj zaštite slobode izražavanja, što podrazumijeva vrlo malu slobodu procjene vlasti kada se primjedbe odnose na pitanje od javnog interesa, osobito na primjedbe o funkcioniranju sudbene vlasti. Ponovio je da ima slučajeva kad je potrebno zaštititi sudbenu vlast od iznimno štetnih i neosnovanih napada zbog važnosti održavanja povjerenja javnosti u sudbenu vlast, a imajući u vidu da suci zbog dužnosti diskrecije ne mogu odgovoriti na njih, no to ne može dovesti do zabrane izražavanja mišljenja pojedinaca o pitanjima od javnog interesa povezanima s funkcioniranjem pravosudnog sustava ili do zabrane bilo kakvog kritiziranja sudbene vlasti uobličenih u vrijednosne sudove koji imaju dostatan činjenični temelj.

Europski je sud prihvatio zaključak domaćih sudova da je sporni članak sadržavao vrijednosne sudove. Međutim, domaći sudovi nisu ispitivali jesu li ti vrijednosni sudovi bili činjenično utemeljeni. U predmetnom članku istaknuta su dva događaja u kojima je sudjelovao sudac i premda je članak sadržavao vrlo oštre kritike, pretjerivanje i grubu metaforu, Europski je sud, suprotno domaćim sudovima, utvrdio da nije bio uvredljiv (primjeri uvredljivih izjava navedeni su primjerice

42 Narodni list d.d. protiv Hrvatske, zahtjev br. 2782/12, od 8. studenoga 2018. 
u predmetu Skatka protiv Poljske ${ }^{43}$ u kojem je zastupnik nazvao suca „,nevažnim kretenom”, „,budalom”, „ograničenim pojedincem”, te „izrazitim kretenom”).

Nadalje Europski je sud zaključio da miješanje u slobodu izražavanja društva podnositelja zahtjeva nije bilo razmjerno stoga što šteta ugledu suca nije bila toliko ozbiljna da bi opravdala iznos naknade neimovinske štete od 50.000,00 kuna, jer hrvatski sudovi dosuđuju 2/3 tog iznosa za duševne boli zbog smrti brata/sestre. Tako visok iznos naknade mogao bi odvratiti građane od otvorene rasprave o pitanjima od javnog interesa te je posljedično Sud utvrdio povredu čl. 10. Konvencije.

\section{ZAKLJUČNA RAZMATRANJA}

Nije sporno da suci nisu i ne bi trebali biti zaštićeni od kritike i ispitivanja (ne)pristranosti njihova rada. Međutim, kod činjenice da sadržaj omalovažavanja (uvredljive izjave) predstavlja negativan vrijednosni sud o nekoj osobi, a da su vrijednosni sudovi iskazi subjektivnog opredjeljenja, uvjerenja ili ocjenjivanja čija se ispravnost (istinitost) ili neispravnost (neistinitost), za razliku od činjenične tvrdnje (o kojoj je riječ kod kaznenog djela klevete), ne može dokazivati, i u sudskoj je praksi jasno izraženo stajalište da je za uvredu s objektivne strane potrebno postojanje izjave koja sadrži u sebi omalovažavanje, a koja ne obuhvaća činjenične tvrdnje. Bitno je, dakle, u svakom konkretnom slučaju ocijeniti radi li se o okolnosti koja se pojavljuje u stvarnosti i čije se postojanje ili nepostojanje može objektivno utvrditi, ili je u pitanju vrijednosni sud, odnosno subjektivna ocjena, zaključak ili mišljenje o drugome, o čemu mogu postojati različita shvaćanja, pa stoga utvrđivanje istinitosti sadržaja takve izjave nije moguće.

U tom smislu, ilustracije radi, radit će se o vrijednosnim sudovima ako se za nekoga kaže da je antipatičan, nepovjerljiv, primitivac, neodgovoran, nesposoban, neugodan ili čudak, ali ako se sud o vrijednosti iznosi u povezanosti s određenim događajem u stvarnosti, onda se može raditi o klevetničkom sadržaju koji može biti predmetom dokazivanja. Ako se za nekoga kaže da je nemoralan, to je vrijednosni sud, ali ako se to izjavi u vezi s određenim postupcima, takva se izjava može dokazivati i može predstavljati osnovu za zaključak da je ipak riječ o kleveti.

Autorice su pokušale, kroz praksu domaćih sudova kao i kroz ESLJP, apstrahirati zajedničke elemente i ključne kriterije za utvrđivanje granice slobode izražavanja kada je u pitanju očuvanje autoriteta sudačke neovisnosti. Čini se kako je ESLJP ipak u određenoj mjeri skloniji veći značaj dati slobodi izražavanja, osobito kada se radi o izražavanju odvjetnika unutar sudnice u okviru zastupanja ili obrane stranaka u sudskim postupcima kao i novinara koji izvješćuju javnost putem medija, čime ipak nije isključio mogućnost upućivanja odvjetničke kritike putem medija, ako se radi o pitanjima od javnog interesa.

43 Skatka protiv Poljske, zahtjev br. 43425/98, od 27. svibnja 2003. 
U potrazi za zaključnim razmatranjem predmetne materije, a imajući u vidu detaljan prikaz kriterija za odlučivanje je li došlo do povrede prava iz čl. 10. u praksi ESLJP-a, kao i prikaz odluka domaćih sudova, od Općinskih do Ustavnog suda, te analizu istih, autorice su poput sudaca koji u procesnoj svakodnevnici imaju pravo i obvezu vaganja suprotstavljenih jednakovrijednih prava kako bi donijeli zakonitu odluku temeljem pravilno i potpuno utvrđenog činjeničnog stanja, našle svrhovitim prikazati dvije strane perceptivne vage koje su ispunile domaći medijski prostor, sve u svrhu iznalaženja ravnoteže između očuvanja autoriteta i neovisnosti sudačke vlasti s jedne starne, te slobode izražavanja s druge.

Naime, razmatrajući ozračje u javnosti u odnosu na sudbenu vlast suci Vrhovnoga suda Republike Hrvatske na Općoj su sjednici 18. svibnja 2021. smatrali svrsishodnim podijeliti s tom istom javnošću svoje viđenje predmetne problematike, ističući, u bitnome:

\section{„Nedopustivo je promicati netrpeljivost prema sucima“}

Zamisli o potrebi reduciranja postignute neovisnosti i samostalnosti sudbene vlasti u suprotnosti su s Ustavom Republike Hrvatske koji propisuje neovisnost $i$ samostalnost sudbene vlasti. Istovremeno, takve su teze izravno suprotne pravnoj stečevini Europske unije koju smo se obvezali poštovati pristupajući Europskoj uniji...

\section{"Pretjerano neutemeljeno kritiziranje"}

Upozoravamo da pretjerivanje pojedinaca u neutemeljenom kritiziranju dovodi do opće sklonosti javnosti tendencioznim krajnostima. To je možda posljedica nedostatka iskustva $i$ znanja koje se stječe radom na sudovima ili nedostatka potpunog poznavanja rada sudaca, ali i želje aktera javnog života za postizanjem popularnosti u političkom okruženju, računajući na to da profesionalni položaj sucima nalaže načelnu suzdržanost u konfliktima koji se događaju u javnom životu.

\section{„Ne osporavamo pravo na slobodno mišljenje”}

Nikome ne osporavamo pravo na slobodno mišljenje i izražavanje, ali od državnih dužnosnika i drugih sudionika koji smatraju da svojim promišljanjima mogu doprinijeti napretku našega društva (uključujući i sudbenu vlast), očekujemo da taj doprinos daju prije svega tamo gdje ih određuje njihov profesionalni položaj (položaj u zakonodavnoj ili izvršnoj vlasti, fakulteti itd.), a ne destruktivnim javnim istupima, bez suvislih zamisli o tomu što i kako treba poduzimati. ${ }^{44}$

Jedanaest dana poslije, u članku objavljenom 29. svibnja 2021. na portalu www. Novilist.hr pod naslovom „Duševne boli sudaca jednostavno su preteške: Tužba od 100.000 eura vrhunac je pravosudne agresije", između ostalog, u svojevrsnoj kolizji s ranije naznačnim shavćanjima sudaca Vrhovnog suda, ističe se: „Najava tužbe suca Zvonka Vrbana protiv Telegrama.hr „teške” čak 100.000 eura zbog tekstova o njegovom stjecanju imovine, prema ocjeni urednika hrvatskih medija i pravnih

44 Opća sjednica Vrhovnog suda od 18. svibnja 2021., Priopćenje za javnost, http://www.vsrh.hr/ EasyWeb.asp?pcpid=564, pristupljeno 17. kolovoza 2021. 
stručnjaka, vrhunac je ,pravosudne agresije” protiv medija i novinara, ali i dosad nezabilježen iznos potraživanja u sudskoj praksi... Suci moraju prihvatiti i osvijestiti da su, kao dio pravosudnog sustava, podložni preispitivanju svojih postupaka i da javnost ima pravo pratiti njihov rad, posebno u okolnostima kakve postoje u odnosu na suca Vrbana... ,Rad sudaca i sve što na njega utječe ili može utjecati, sigurno su pitanja od opravdanog javnog interesa. To je, uostalom, potvrdio i Europski sud za ljudska prava." ${ }^{45}$

Nije svrha sloboda koje jamče Ustav RH i Europska konvencija o ljudskim pravima sniziti prosječnu razinu novinarskog pisanja, baviti se navijačkim novinarstvom te se, zloupotrebljavajući medijski prostor, osobno obračunavati sa svakim neistomišljenikom na neprihvatljiv način, a potom se pozivati na javni interes, kao što nije smisao sudbene vlasti nedodirljivost, arbitrarnost i samovolja u bilo kojem obliku.

Tek odgovoran odnos prema svom novinarskom privilegiju koji nedvojbeno predstavlja pozicija kreiranja javnog mišljenja, dopušta pozivanje na zaštitu koju novinarima pružaju međunarodni, regionalni i nacionalni propisi, jednako kao što tek suđenje po Ustavu, zakonu i međunarodnim ugovorima koji su dio pravnog poretka Republike Hrvatske te primjena drugih propisa koji su doneseni sukladno Ustavu, međunarodnim ugovorima ili zakonima Republike Hrvatske, humano ponašanje te primjena najviših etičkih načela u skladu sa standardima profesionalne i opće kulture, neovisnost u odnosu na društvo, društvene skupine, jednakost, dostojanstvo i marljivost u obnašanje sudačke dužnosti, daju jedini mogući legitimitet dopuštenju ograničenja prava na slobodu izražavanja.

\section{LITERATURA}

\section{Članci i knjige:}

1. Bychawska-Siniarska, D. (2017.). Zaštita prava na slobodu izražavanja po Evropskoj konvenciji o ljudskim pravima, priručnik za pravnike. Strasbourg: Vijeće Europe

2. Marochini, M. (2014.). "The interpretation of the European Convention on Human Rights". Zbornik radova Pravnog fakulteta u Splitu, 51 (1), 63-84. Preuzeto s https:// hrcak.srce.hr/116319

3. Guide on Article 10 of the European Convention on Human Rights, Freedom of expression (2020). Strasbourg: Vijeće Europe

\section{Presude Europskog suda za ljudska prava:}

1. Ashby Donald i drugi protiv Francuske, zahtjev br. 36769/08, od 10. I. 2013.

2. Aurelian Oprea protiv Rumunjske, zahtjev br. 12138/08, od 19. I. 2016.

3. Bono protiv Francuske, zahtjev br. 29024/11, od 15. XII. 2015.

4. Castells protiv Španjolske, zahtjev br. 11798/85, od 23. IV. 1992.

45 Novi list, https://www.novilist.hr/novosti/hrvatska/suci-protiv-novinara-tuzba-od-100-000-euravrhunac-je-pravosudne-agresije/ (29. svibnja 2021.), pristupljeno 17. kolovoza 2021. 
5. De Haes i Gijsels protiv Belgije, zahtjev br. 19983/92, od 24. II. 1997.

6. Delfi As protiv Estonije, zahtjev br. 64569/09, od 16. VI. 2015.

7. Hanyside protiv Ujedinjenog Kraljevstva, zahtjev br. 5493/72, od 7. XII. 1976.

8. Hauschildt protiv Danske, zahtjev br. 10486/83, od 24. V. 1989.

9. Jersild protiv Danske, zahtjev br. 15890/89, od 24. IX. 1994.

10. July i SARL Libération protiv Francuske, zahtjev br. 20893/03, od 14. II. 2008.

11. Kyprianou protiv Cipra, zahtjev br. 73797/01, od 15. XII. 2005. (VV)

12. Morice protiv Francuske, zahtjev br. 29369/10, od 23. IV. 2015. (VV).

13. Muller i drugi protiv Švicarske, zahtjev br. 10737/84, od 24. V. 1988.

14. Narodni list d.d. protiv Hrvatske, zahtjev br. 2782/12, od 8. XI. 2018.

15. Nikula protiv Finske, zahtjev br. 31611/96, od 21. III. 2002.

16. Open Door Counselling i Dublin Well Woman protiv Irske, zahtjevi br. 14234/88 i 14235/88, od 19. X. 1992.

17. Otto Preminger Institut protiv Austrije, zahtjev br. 13470/87, od 20. IX. 1994.

18. Radobuljac protiv Hrvatske, zahtjev br. 51000/11, od 28. VI. 2016.

19. Rodriguez Ravelo protiv Španjolske, zahtjev br. 48074/10, od 12. I. 2016.

20. Skatka protiv Poljske, zahtjev br. 43425/98, od 27. V. 2003.

21. Sunday Times protiv Ujedinjenog Kraljevstva (br. 1), zahtjev br. 6583/74, od 26. IV. 1979.

22. Sunday Times protiv Ujedinjenog Kraljevstva (br. 2), zahtjev br. 13166/87, od 26. XI. 1991.

23. Surek protiv Turske (br. 1), zahtjev br. 26682/95, od 8. VII. 1999. (VV)

24. Wingrowe protiv Ujedinjenog Kraljevstva, zahtjev br. 17419/90, od 15. XI. 1996.

25. Žugić protiv Hrvatske, zahtjev, br. 3699/08, 31. V. 2011.

\section{Presude i rješenja Hrvatskih sudova:}

1. Općinski građanski sud u Zagrebu br. P-755/14 od 26. ožujka 2015.

2. Općinski kazneni sud u Zagrebu br. K-281/14 od 12. srpnja 2016.

3. Rješenje Trgovačkog suda u Rijeci broj: P-408/2017-39 od 23. travnja 2018.

4. Rješenja Visokog trgovačkog suda Republike Hrvatske broj: Pž-3075/2018-2 od 13. srpnja 2018.

5. Županijski sud u Bjelovaru br. Kž-222/2016 od 13. listopada 2016.

6. Županijski sud u Zagrebu br. Gž-3690/15 od 13. veljače 2018.

\section{Odluke i rješenja Ustavnog suda RH:}

1. Odluka br. U-III/2886/2011. od 1. lipnja 2016.

2. Odluka br. U-III/63/2017 od 26. veljače 2019.

3. Odluka br. U-III/3373/2018 od 10. srpnja 2019.

4. Odluka br. U-III/3675/2018 od 15. siječnja 2020.

5. Rješenje br.U-III-3285/2002 od 28. ožujka 2003., 
6. Rješenje br. U-III-231/2003 od 28. ožujka 2003.

7. Rješenje br.U-III-4772/2004 od 25. veljače 2005.

\section{Mrežni izvori:}

1. Hrvatska enciklopedija, mrežno izdanje. Leksikografski zavod Miroslav Krleža, 2021. <http://www.enciklopedija.hr/Natuknica.aspx?ID=4770, pristupljeno 25. kolovoza 2021.

2. Kodeks časti hrvatskih novinara, dostupno na https://www.google.com/search?q=ko deks+\%C4\%8Dasti+hrvatskih+novinara\&oq=kodeks+\%C4\%8Dasti+\&aqs=chrome $.0 .69 \mathrm{i} 59 \mathrm{j} 69 \mathrm{i} 57.3995 \mathrm{j} 0 \mathrm{j} 4 \&$ sourceid=chrome\&ie=UTF-8\#, pristupljeno 15 . kolovoza 2021.

3. Novi list, https://www.novilist.hr/novosti/hrvatska/suci-protiv-novinara-tuzba-od100-000-eura-vrhunac-je-pravosudne-agresije/ (29. svibnja 2021.), pristupljeno 17. kolovoza 2021.

4. Opća sjednica Vrhovnog suda od 18. svibnja 2021., Priopćenje za javnost, http:// www.vsrh.hr/EasyWeb.asp?pcpid=564, pristupljeno 17. kolovoza 2021.

\section{Pravni izvori:}

1. Ustav Republike Hrvatske, pročišćeni tekst, NN 56/90, 135/97, 08/98, 113/00, 124/00, 28/01, 41/01, 55/01, 76/10, 85/10, 05/14.

2. Ustavni zakon o Ustavnom sudu Republike Hrvatske, pročišćeni tekst, NN br. 99/99, 29/02, 49/02.

3. Zakon o potvrđivanju EKLJP-a i Protokola br. 1., 4., 6., 7., 11. i 14. uz EKLJP, NN, Međunarodni ugovori, dalje u tekstu: MU, br. 18/97, 6/99 - pročišćeni tekst i 8/99, Protokoli br. 12., 13. i 14., Zakon o potvrđivanju Protokola br. 12. uz EKLJP, Zakon o potvrđivanju Protokola br. 13. uz EKLJP, o ukidanju smrtne kazne u svim okolnostima, NN, MU br. 14/02 i Zakon o potvrđivanju Protokola br. 14. uz EKLJP, o izmjeni nadzornog sustava Konvencije, NN, MU br. 1/06. Još: objave o stupanju na snagu Protokola br. 12. uz EKLJP, NN, MU, br. 9/05, Protokola br. 13 uz EKLJP, NN, MU, br. 13/03 i Protokola br. 14. uz EKLJP, NN, MU, br. 2/10.

4. Kazneni zakon, NN 125/2011.

5. Kodeks odvjetničke etike, $\mathrm{NN}$ br. 64/07, 72/08 i 64/18

6. Zakon o medijima, pročišćeni tekst, NN br. 59/04, 84/11, 81/13Zakon o odvjetništvu, NN br. 09/94, 117/08, 50/09, 75/09, 18/11Zakon o parničnom postupku, NN br. $53 / 91-89 / 14$

7. Zakon o sudovima, NN br. 28/13-67/18

8. MEĐUNARODNI PAKT O GRAĐANSKIM I POLITIČKIM PRAVIMA usvojen na Općoj skupštini Ujedinjenih naroda, 16. prosinca 1966. godine (rezolucija br. 2200 $\mathrm{A} / \mathrm{XXI} /$ )

9. Opća deklaracija o ljudskim pravima, usvojena i proglašena na Općoj skupštini Ujedinjenih naroda, Rezolucijom 217 A (III)

10. POVELJA EUROPSKE UNIJE O TEMELJNIM PRAVIMA (2016/C 202/02) 
11. Afrička povelja o ljudskim pravima i pravima naroda (Povelja iz Banjula) iz 1986.

12. Američka konvencija o ljudskim pravima (tzv. Pakt iz San Josea) iz 1969.

\title{
MAINTAINING THE AUTHORITY AND IMPARTIALITY OF THE JUDICIARY AS A PERMISSIBLE RESTRICTION ON THE RIGHT TO FREEDOM OF EXPRESSION - CROATIAN AND CONVENTION PERSPECTIVE
}

\begin{abstract}
Freedom of expression, as one of the foundations of a democratic society, is a qualified Convention right that can always, when the preconditions are met, be subjected to restrictions. One of the permissible restrictions, i.e. legitimate aim stated in Art. 10 of the Convention, is maintaining the authority and impartiality of the judiciary. Also, the Constitution of the Republic of Croatia guarantees freedom of expression in Art. 38, while Art. 16 prescribes the permissible restrictions on freedoms from the Constitution, although it does not mention specifically maintaining the authority and impartiality of the judiciary. Despite the small number of cases examining restrictions on freedom of expression in order to maintain the authority and impartiality of the judiciary, authors consider those cases significant and will therefore present both the domestic practice at all levels of the judiciary and the practice of the European Court. The authors presented the mentioned cases primarily through two groups of cases: those where the persons who considered that their freedom of expression had been violated were journalists, as well as those where they were lawyers, who exercised their freedom of expression inside or outside the courtroom.
\end{abstract}

Key words: freedom of expression, maintaining the authority and impartiality of the judiciary, permissible restrictions of freedom of expression, national courts, European Court of Human Rights 